\title{
Olympiad Material Development for Improving of Teacher Professionalism MGMP SMP regency of Agam West Region
}

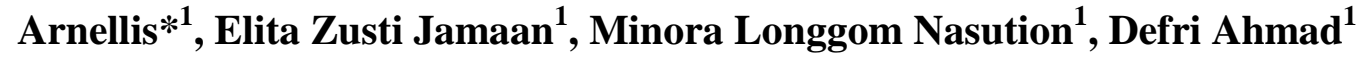 \\ ${ }^{l}$ Jurusan Matematika Fakultas Matematika dan Ilmu Pengetahuan Alam Universitas Negeri Padang \\ Jln Prof Dr Hamka Air Tawar Padang, West Sumatera, Indonesia \\ * Correspondence: arnellis_math@fmipa.unp.ac.id; Tel.: +62-813-7471-1445
}

Diterima 1 Februari 2018, Disetujui 15 Februari Dipublikasikan Maret 2018

\begin{abstract}
Based on observations and interviews with several mathematics teachers of Agam west region, the teacher's lack of knowledge about non-routine materials and problems in mathematical olympiad. Teachers rarely attend the olympic training so that teachers do not know much about nonroutine questions, techniques to solve the problem. Based on these observations and the facts there is and so the importance of making the strengthening of mathematics material for teachers. The purpose of this article is to provide the strengthening of mathematics olympiad material so that teachers can improve their professional development, especially in making and solving the olympic problem in teachers of SMP MGMP west Agam District. Based on the evaluation it can be seen that generally the participants of community service in general have sufficiently understood the material in designing the problem and how to solve the existing problems in the Olympics in order to improve the quality of OSN participants from west Agam District. This success is shown by the teacher is able to design and make problems and solve problems related to mathematics olympiad.
\end{abstract}

Keywords - mathematics Olympiad, professionalism, competition, achievement, non-routine materials

\section{Pendahuluan}

Guru adalah salah satu jenis jabatan profesional di dalam bidang kependidikan. Tugas profesional guru dapat dipilah menjadi empat fungsi sekalipun di dalam praktik merupakan satu kesatuan terpadu saling terkait, mendukung dan memperkuat satu terhadap aspek yang lain.Empat fungsi yang dimaksud adalah guru sebagai pendidik, pengajar, pelatih, dan pembimbing. Hasil studi dari pakar pendidikan [1], menyimpulkan bahwa guru merupakan faktor kunci yang paling menentukan dalam keberhasilan pendidikan dinilai dari prestasi belajar siswa.Prestasi siswa hendaknya diiringi dengan prestasi guru baik secara akademik maupun dalam ekstrakurikuler seperti kegiatan olimpiade. Untuk seorang guru perlu mengetahui dan dapat menerapkan beberapa prinsip mengajar agar ia dapat menerapkan beberapa prinsip mengajar agar ia dapat melaksanakan tugasnya secara professional, yaitu sebagai berikut [2]: a. Guru harus dapat membangkitkan perhatian peserta didik pada materi pelajaran yang diberikan serta dapat mengggunakan berbagai media dan sumber belajar yang bervariasi.

b. Guru harus dapat membangkitkan minat peserta didik untuk aktif dalam berfikir serta mencari dan menemukan sendiri pengetahuan.

c. Guru harus dapat membuat urutan (sequence) dalam pemberian pelajaran dan penyesuaian dengan usia dan tahapan tugas perkembangan peserta didik.

d. Guru perlu menghubungkan pelajaran yang akan diberikan dengan pengetahuan yang telah dimiliki peserta didik (kegiatan apersepsi), agar peserta didik menjadi lebih mudah dalam memahami pelajaran yang diterimanya.

e. Sesuai dengan prinsip repetisi dalam proses pembelajaran, diharapkan guru dapat menjelaskan unit pelajaran secara 
berulang-ulang hingga tanggapan peserta didik menjadi jelas.

f. Guru wajib memerhatikan dan memikirkan korelasi antara mata pelajaran dan/atau praktik nyata dalam kehidupan sehari-hari.

g. Guru harus terus menjaga konsentrasi belajar para peserta didik dengan cara memberikan kesempatan berupa pengalaman secara langsung, mengamati/meneliti, dan menyimpulkan pengetahuan yang didapatnya.

h. Guru harus dapat mengempangkan sikap peserta didik dalam membina hubungan sosial, baik di dalam kelas maupun diluar kelas.

i. Guru harus menyelidiki dan mendalami perbedaan peserta secara individual agar dapat melayani siswa sesuai dengan perbedaan tersebut

Salah satu kompetisi yang dilakukan secara rutin dan berkelanjutan oleh pemerintah Indonesia melalui Kementrian Pendidikan dan Kebudayaan adalah [3] kegiatan Olimpiade Sains Nasional ( OSN ) untuk siswa dan Olimpiade Guru Nasional (OGN) untuk guru yang dilaksanakan sesuai bidang keilmuan yaitu matematika. Kenyataan di lapangan hanya sedikit guru yang mau dan mampu dalam membina olimpiade tersebut.Hal ini dapat dilihat dari dampak hasil OSN nasional pada beberapa tahun terakhir, tim OSN SMP Kabupaten Agam khusus bagian Barat baik guru maupun siswa belum pernah memperoleh hasil yang baik untuk bidang matematika, dengan kata lain belum ada guru dan siswa yang sampai lolos ke tingkat nasional. Kendala utama adalah guru belum mampu mengembangkan materi matematika, sehingga mengalami kendala dalam menguasai materi olimpiade.

Upaya peningkatan kualitas guru perlu dilakukan melalui berbagai cara antara lain: penataran/pelatihan guru, peningkatan profesionalisme guru dan perlu disikapi sedini mungkin (semenjak tahap awal pelaksanaan kegiatan olimpiade) [4], [5], [6]. Dengan demikian, penguatan/pembinaan guru sebelum siswanya mengikuti olimpiade sangat perlu dilaksanakan secara intensif. Melalui pembekalan yang intensif siswa dapat fokus untuk ikut berkompetisi dalam olimpiade. Organisasi pengembangan profesi guru melalui Musyawarah Guru Mata pelajaran (MGMP) sejatinya sudah melakukan peranan dalam meningkatkan pengetahuan guru terhadap pendalaman materi, metode maupun teknik pembelajaran.

Forum MGMP ini dapat diberdayakan sebagai wadah bagi guru untuk dapat meningkatkan penguasaan materi olimpiade secara berkolaborasi. Pengetahuan guru dalam materi olimpiade rendah merupakan salah satu permasalahan yang harus disikapi. Untuk itu kegiatan pengabdian masyakat ini bermaksud untuk membekali guru akan kemampuan penguatan materi olimpiade yang berkesinambungan. Ini merupakan upaya dan langkah nyata dalam bentuk pembimbingan sebagai wujud kegiatan pengabdian, sehingga guru dan berdampak pada siswa mampu berkarya dan berprestasi dalam berbagai kegiatan lomba olimpiade matematika dan didukung oleh berbagai pihak.

\section{Solusi/Teknologi}

Pelatihan penguatan materi olimpiade bagi guru-guru MGMP SMP Kabupaten Agam wilayah Barat menjadi target dalam kegiatan pengabdian ini yang berjumlah 32 orang guru. Bagi sebagian besar guru, membina olimpiade matematika pada siswa merupakan hal yang sulit ,apalagi ikut berkompetisi di ajang OGN berat untuk ikut lomba. Kategori sulit dan berat yang dirasakan pada dasarnya karena penguasaan dan pengerjaan latihan soal olimpiade matematika yang sulit. Oleh karena itu, selama pelatihan ini berlangsung diharapkan guru-guru mampu:(1) Menguasi materi olimpiade matematika yang meliputi materi bilangan, , aljabar, geometri,dan kombinatorik, Muchlis [7]; (2) Menyelesaikan soal-soal olimpiade matematika tingkat kota dan provinsi secara berkelompok, (3) Merancang dan menyusun soal olimpiade matematika oleh guru secara individu 
dengan didampingi oleh pembimbing

Menyelesaikan soal yang disusun oleh teman lain dengan sistim silang.

Bentuk pelatihan penguatan materi olimpiade dalam kegiatan pengabdian kepada masyrakat ini dibagi menjadi beberapa tahap yaitu: (1) ceramah/penyuluhan dan bimbingan, metode ini digunakan untuk menjelaskan tentang materi- materi yang sukar dalam olimpiade disertai dengan berbagai macam contoh soal olimpiade tingkat kab/kota sampai nasional, (2) pemberian pelatihan secara klasikal, melalui metode ini peserta pengabdian berlatih mengerjakan soal olimpiade matematika dengan bimbingan tim pengabdian, (3) pemberian pelatihan secara mandiri, guru berlatih secara individu menyusun soal-soal olimpiade matematika, (4) presentasi secara individu, para peserta secara individu mempresentasikan soal yang telah disusun, (5) presentasi secara kelompok, memberi masukan dari peserta pelatihan dan tim pengabdian. Dengan kegiatankegiatan tersebut diharapkan penguatan dan keterampilan guru-guru SMP dalam menyusun dan menyelesaikan soal olimpiade lebih meningkat.

\section{Hasil dan Diskusi}

Adapun hasil yang dicapai pada kegiatan pelatihan penguatan materi olimpiade matematika untuk meningkatan profesionalisme guru MGMP SMP di Kabupaten Agam wilayah Barat adalah sebagai berikut:

\section{Inventarisasi Modul dan Bank Soal Olimpiade Matematika}

Pada tahap ini hasil yang diperoleh adalah kesediaan mitra kerja (pihak MGMP ) untuk mengikuti Pelatihan Penguatan Materi Olimpiade untuk Pengembangan Profesionalisme Guru-Guru SMP MGMP Kabupaten Agam Wilayah Barat. Pada proposal hanya anggota MGMP saja sebagai mitra kerja, namun karena antusias yang tinggi dari guru -guru sekolah lain, maka mitra bertambah dari lorang dari setiap sekolah yang ada di kabupaten Agam wilayah Barat dengan jumlah peserta seluruhnya sebanyak 32 orang guru. Dari hasil pelatihan setiap sekolah sudah memiliki modul dan bank soal olimpiade matematika

\section{Peningkatan Hubungan Tim Dengan Pihak} Sekolah

Dalam kegiatan pelatihan ini, keberlangsungan kerja sama tetap terjalin baik. Komunikasi tim pengabdian dengan pengurus MGMP SMP dan juga guru-guru matematika berjalan dengan baik dan penuh keakraban selama pelatihan dan pendampingan bimbingan olimpiade matematika yang berkelanjutan untuk ke depannya.

\section{Pencapaian Indikator}

Sesuai dengan target dari kegiatan ini yaitu dimulai dari pemaparan tentang materi olimpiade, pelatihan penyusunan soal olimpiade matematika dilanjut dengan penyelesaian dan presentasi di depan kelas masing-masing guru sampai akhirnya diperoleh ringkasan materi olimpiade matematika dan trik cara menyelesaikan soal olimpiade matematika. Selama pembimbingan ini berlangsung, ada banyak hal yang dihadapi oleh tim pengabdian. Diantaranya (1) kegiatan guru-guru yang juga padat di sekolah sehingga terbentur dengan waktu pelatihan; (2) minimnya pengetahuan guru terhadap materi pengembangan ke olimpiade. Namun dengan kerjasama dan komunikasi yang baik antara tim pengabdian dengan masingmasing peserta, masalah di atas dapat diatasi.

\section{Kesimpulan}

Pelaksanaan kegiatan pengabdian kepada masyarakat untuk guru-guru matematika yang tergabung dalam Musyawarah Guru Mata Pelajaran (MGMP) SMP Matematika Kabupaten Agam Wilayah Barat dapat disimpulkan berhasil dalam memahami, merancang soal dan menyelesaikan beberapa kasus yang berhubungan dengan soal-soal yang diujikan dalam olimpiade matematika.

Keberhasilan ini ditunjukkan dengan adanya keadaan antara lain:

1. Guru-guru yang sudah mampu merancang dan membuat soal serta menyelesaikan soal terkait olimpiade tersebut dengan menggunakan metode 
dan cara yang dijelaskan oleh tim dan narasumber.

2. Adanya respon yang positif dari peserta, yang ditunjukan dengan pertanyaan dan tanggapan yang diberikan selama berlangsungnya kegiatan.

3. Beberapa guru sudah dapat memprediksi dan merancang soal yang menyerupai atau mendekati soal-soal olimpiade.

4. Tingkat kepuasan peserta yang ditunjukan dari respon dan hasil dari angket yang diberikan.

\section{SARAN}

Dari tanggapan dan pertanyaan peserta pengabdian, dalam hal ini peserta penguatan materi olimpiade terhadap guru-guru matematika SMP Kabupaten Agam wilayah Barat, maka saran yang dapat diberikan adalah agar guru-guru termotivasi dan lebih bersemangat untuk meningkatkan kompetensi profesionalnya terutama dalam menghadapi soal-soal non rutin. Sebagai guru harus senantiasa mengembangkan dan menguasai kompetensi dan kualifikasi yang dibutuhkan terutama dalam menghadapi tuntutan kurikulum 2013 serta tuntutan kompetisi saat sekarang ini di bidang matematika. Hendaknya pihak sekolah dalam hal ini kepala sekolah yang bersinergi dengan Dinas Pendidikan selalu mendukung dan rnemberi fasilitas bagi guru untuk meningkatkan kualitas guru-guru matematika yang diwadahi oleh MGMP Matematika SMP guna meningkatkan profesionalitas guru

\section{Ucapan Terima Kasih}

Penulis mengucapkan terimakasih kepada Guru Matematika SMP Kabupaten Agam Wilayah Barat yang telah berpartisipasi aktif dalam kegiatan.

\section{Pustaka}

[1] Jalal, Fasli dan Musthafa, Bahrudin. 2001. Education Reform, in the Context of Regional Autonomy: The Case of Indonesia. Ministry of National Education. Jakarta.
[2] Hamzah B. Uno,Profesi Kependidikan.Jakarta : Bumi Aksara, 2007

[3] Depdikbud, Kebijakan Pengembangan Profesi Guru, Badan PSDMPK-PMP, Jakarta; 2012.

[4] Undang Undang Republik Indonesia Nomor 20 Tahun 2003. Tentang Sistem Pendidikan Nasional.

[5] Undang-Undang Republik Indonesia Nomor 14 Tahun 2005 Tentang Guru dan Dosen, Lembaran Negara Republik Indonesia Nomor 157, 2005; Jakarta.

[6] Peraturan Menteri Pendayagunaan Aparatur Negara dan Reformasi Birokrasi Nomor 16 Tahun 2009, tentang Jabatan Fungsional Guru dan Angka Kreditnya.2009, Jakarta.

[7] Muchlis, A (2005). Peningkatan Mutu Pendidikan Melalui Kompetisi Yogyakarta: PPPG Matematika. Naskah seminar, tidak diterbitkan. 